\title{
Dealing with Ebola virus disease in Spain: epidemiological inquiries received by the Department of Public Health Alerts, April to December 2014
}

V Blaya-Nováková ${ }^{1}$, MÁ Lópaz-Pérez ${ }^{1}$, I Méndez-Navas ${ }^{1}$, MF Domínguez-Berjón ${ }^{1}$, J Astray-Mochales ${ }^{1}$, Working group of the Madrid Ebola outbreak investigation team ${ }^{2}$

1. Epidemiology Area, Subdirectorate of Health Promotion and Prevention, General Directorate of Primary Care, Health Authority of the Autonomous Community of Madrid, Madrid, Spain

2. Members of the working group are listed at the end of the article

Correspondence: Vendula Blaya-Nováková (vendula.novakova@gmail.com)

Blaya-Nováková V, Lópaz-Pérez MÁ, Méndez-Navas I, Domínguez-Berión MF, Astray-Mochales J. Dealing with Ebola virus disease in Spain: epidemiological

inquiries received by the Department of Public Health Alerts, April to December 2014. Euro Surveill. 2015;20(44):pii=30058. DOI: http://dx.doi.org/10.2807/15607917.ES.2015.20.44.30058

Article submitted on 06 March 2015 / accepted on 08 July 2015 / published on 05 November 2015

We describe the inquiries regarding Ebola virus disease (EVD) received by the Department of Public Health Alerts of the Community of Madrid between April and December 2014. A total of 242 inquiries were received. Consultations were initiated most frequently by hospital clinicians (59 inquiries, 24\%), private citizens (57 inquiries, $24 \%$ ) and primary care physicians ( 53 inquiries, $22 \%$ ). The most frequent topic of inquiry was possible EVD in a patient (215 inquiries, $89 \%)$. Among these, 31 persons (14\%) presented both EVD-compatible symptoms and epidemiological risk factors, and 11 persons ( $5 \%$ ) fulfilled the criteria for a person under investigation. Recent travel abroad was reported in 96 persons (45\%), but only 32 (15\%) had travelled to an EVD-affected area. Two high-risk and one low-risk contact were identified through these inquiries. Low specificity of the EVD symptoms led to many difficulties in protocol application. Ineffective communication with healthcare professionals and unfamiliarity with the EVD protocols caused many case classification errors. A rapid consultation service by telephone is essential for providing qualified advice during emergencies. Our experience may help other countries dimension their activities and resources for managing similar exceptional outbreaks in the future.

\section{Introduction}

The ongoing outbreak of Ebola virus disease (EVD) in West Africa is the largest registered outbreak of this disease in history. Liberia, Sierra Leone and Guinea have been affected the most, with more than 27,000 cases and over 11,000 deaths between December 2013 and June 2015 [1]. Isolated imported cases or small outbreaks with secondary transmission of EVD have also been reported from Nigeria, Senegal, Spain, the United States (US), Mali, the United Kingdom and Italy [2-8].
The World Health Organization first announced the EVD outbreak at the end of March 2014 [9], and the Spanish Ministry of Health, Social Services and Equality $(\mathrm{MoH})$ issued the initial Ebola virus public health warning on 1 April 2014 [10]. On 7 August 2014, the Spanish government decided to repatriate a Spanish healthcare worker from Monrovia (Liberia), who had tested positive for the Ebola virus. The missionary was admitted to the La Paz-Carlos III Hospital Complex, a designated reference centre for management of infectious diseases, but died on 11 August. On 22 September, a second Spanish healthcare worker who was also suffering from EVD was repatriated from Sierra Leone and admitted to the same reference hospital, where he died on 25 September. On 6 October, the Spanish National Reference Laboratory confirmed the first human-tohuman transmission of EVD outside of Africa in one of the healthcare workers who provided care for the second repatriate $[4,11,12]$.

Spain is administratively divided into 17 Autonomous Communities which have their own healthcare and public health systems; the role of the $\mathrm{MoH}$ is to act on interregional, national and international level. The Community of Madrid has particular experience in the management of public health threats of international importance given the presence of an international airport and the aforementioned La Paz-Carlos III Hospital Complex. After the arrival of the first repatriate, the Community of Madrid activated its International Alert Management Protocol and an Ebola Coordination Centre, led by the Department of Public Health Alerts of the Community of Madrid (the Department). The objective of this study was to describe the EVD-related inquiries received by the Department between 1 April and 2 December 2014, when the Spanish Ebola outbreak was officially declared to be over [13]. 


\section{FIGURE 1}

Inquiries related to Ebola virus disease received by the Department of Public Health Alerts, Community of Madrid, Spain, 1 April-2 December $2014(\mathrm{n}=242)$

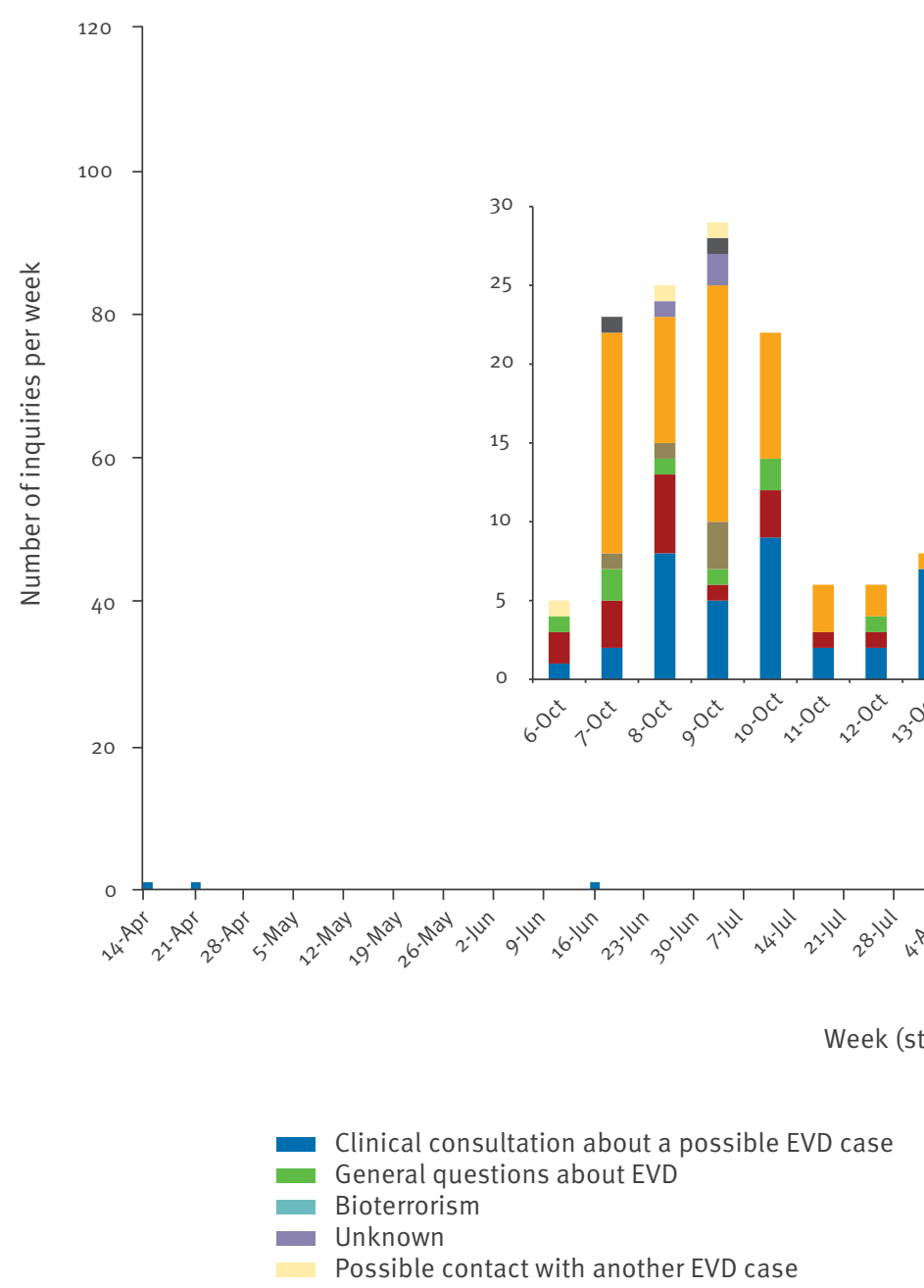

EVD: Ebola virus disease.

\section{Methods}

The Department is in charge of coordinating the response to the public health alerts in the Community of Madrid. Depending on the time of day, the EVD alerts are received either by the staff of the Department (office hours 08:00-15:30) or by an on-call public health officer through the Rapid Public Health Alert System (Sistema de Alerta Rápida en Salud Pública, SARSP), created by the Department in 2003 in response to the SARS epidemic (weekdays 15:30-08:00, weekends and holidays).

The Ebola Coordination Centre is formed by the Department, the SARSP and the Madrid Medical Emergency Service (SUMMA 112). The principal activities of the Ebola Coordination Centre are: classification of patients according to the epidemiological criteria, declaring the person as under investigation for EVD, ordering collection of a sample for PCR analysis, coordination of the transport of the samples to the National
Reference Laboratory for Ebola virus testing, activation of the transport of persons under investigation or confirmed cases to the reference hospital, initial epidemiological survey of the patient, technical advice to healthcare professionals regarding the protocols, and answering the questions of contacts of the EVD cases.

The EVD alerts and EVD-related inquiries are reported via one of the three following paths: (i) The Border Health Control physician reports a person under investigation $[14,15]$ directly to the Department or SARSP who activate the alert protocol and transport the patient to the designated hospital (La Paz-Carlos III Hospital Complex); (ii) Persons who present symptoms compatible with EVD and call the free emergency telephone number 112 are transferred to the medical coordinators of SUMMA 112 who carry out the initial evaluation and report the person to the Department or SARSP for further epidemiological evaluation; (iii) Primary care or hospital clinicians report their suspicion of a patient 


\section{FIGURE 2}

Monthly inquiries received by the Department of Public Health Alerts. Community of Madrid, Spain, 1 April-2 December $2014(\mathrm{n}=518)$

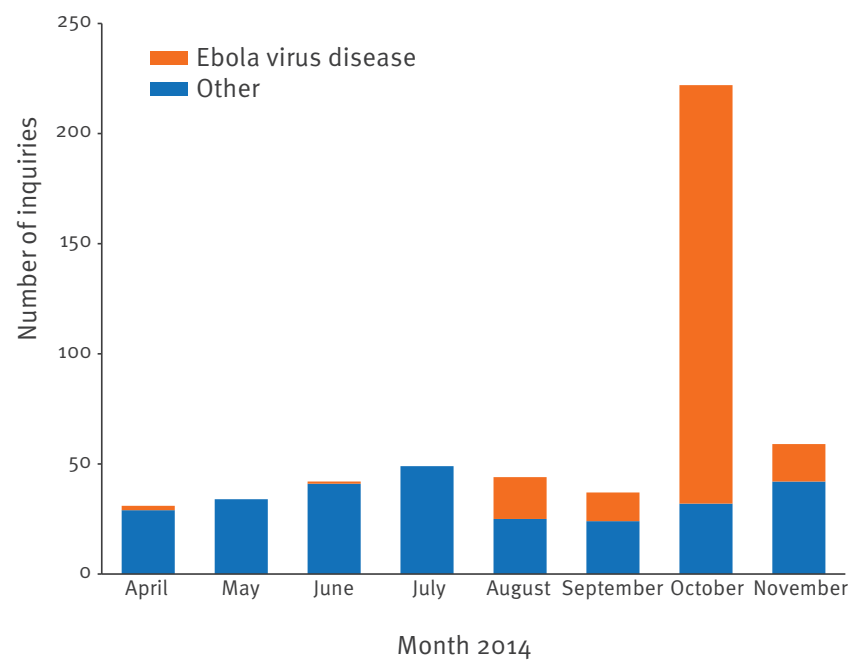

that could have EVD through a free telephone number 061 to the medical coordinators of SUMMA 112, who forward the alert to the Department or SARSP.

All inquiries to the Department have therefore been previously evaluated either by a physician or by the emergency services staff. This study includes all EVDrelated inquiries received by the Department in the period from 1 April to 2 December 2014. The data were extracted from the database of public health alerts, which is part of the Public Health Information System (Sistema de Información de Salud Pública, SISPAL), and completed with information from SUMMA 112 call logs and public health officers' notes. Information collected for the purpose of the present study comprised the date of the inquiry, notifier, topic of the inquiry, age and sex of the person concerned, presence of symptoms, recent travel abroad including travel dates and country visited, fulfilment of clinical and epidemiological case criteria, monitoring and results of the Ebola virus PCR.

The criteria that had to be met for declaring a person as under investigation for EVD are summarised in the Box [14]:

\section{Results}

Between 1 April 2014 and 2 December 2014, 242 telephone inquiries related to EVD were received in the Department (Figure 1). The proportion of EVD-related inquiries in relation to the total number of monthly inquiries to the Department is represented in Figure 2. Three additional epidemiologists and one administrative worker were hired for a period of three months to help deal with the workload related to the EVD outbreak.
Inquiries originated most frequently from clinicians: hospital clinicians initiated $59(24 \%)$ and primary care physicians 53 inquiries (22\%). Private citizens made 57 inquiries ( $24 \%$, Table 1$)$. The most common topic was possible EVD in a patient (133 inquiries, $55 \%$ ), followed by concerns about possible contact with the secondary EVD case (58 inquiries, $24 \%$, Table 1). Eight inquiries $(3 \%)$ were complaints related to the management of the EVD outbreak and three calls (1\%) were alerts about possible bioterrorist attacks: two separate incidents of envelopes containing a piece of red-stained fabric and marked as 'Ebola'.

Of all inquiries, 215 (89\%) were clinical inquiries that concerned a possible case of EVD (133 clinical consultations about possible EVD in a patient, 62 concerns about possible contact with an EVD case and 20 consultations related to contact monitoring). Information about sex was available for 208 subjects (97\%): 115 were men ( $55 \%$ ). The mean age was 37.3 years (standard deviation:15.1; range: $0-86$; information available for $66 \%$ of the persons). In total 158 calls were about persons who had some symptoms consistent with EVD (73\%; Table 2), but only 31 (14\%) fulfilled strictly the clinical criteria of a person under investigation $[14,15]$.

The most common EVD-compatible symptoms were fever or dysthermia, present in 124 cases $(78 \%$ of persons with symptoms; Table 3 ). The epidemiological criterion was fulfilled in 54 persons (25\%). Eleven cases (5\%) fulfilled both criteria; four of these 11 cases were tested for Ebola virus, the remaining seven cases were not tested because alternative diagnosis or clarifications on the patient's history were obtained or because symptoms resolved before a blood sample for PCR was taken (the sample collection had to be approved in advance by the Department in order to coordinate the sample transport to the reference laboratory, which led to some delays). Another 11 cases (5\%) were tested for EVD although they fulfilled only one of the two criteria: four of them were travellers from EVD-affected countries exhibiting some EVD-compatible symptoms and seven were healthcare workers who had had professional contact with an EVD case and presented low-grade fever that did not reach the established threshold; one of them was the secondary EVD case. In total, 15 cases were tested and all results were negative except for the secondary EVD case. An alternative diagnosis was available for 30 cases, the most common being malaria (12 cases, $8 \%$ of symptomatic persons) and traveller's diarrhoea (three patients, $2 \%$ ).

Ninety-six inquiries ( $45 \%$ of the clinical inquiries) were related to reported recent travel abroad (less than 21 days before the onset of symptoms) and the callers were mainly physicians ( 80 consultations, $83 \%$ ). Nine inquiries were initiated by private citizens $(9 \%)$ and seven by other authorities ( $7 \%$ ). The inquiries were most frequently related to travels to Nigeria (23 inquiries, 24\%) and Equatorial Guinea (16 inquiries, 17\%). Only 32 consultations regarding travellers involved a 
Definition of person under investigation for Ebola virus disease, Spain, 1 April-2 December 2014

Epidemiologic criteria - at least one of the following expositions in the previous 21 days:

- $\quad$ travel to an area with EVD transmission,

- contact with an EVD case (under investigation or confirmed) or with their body fluids or biological samples.

Clinical criteria:

- fever of $>38.6^{\circ} \mathrm{C}$ and any of the following symptoms: intense headache, vomiting, diarrhoea, abdominal pain, any unexplained haemorrhagic manifestation or multiple organ failure,

- $\quad$ sudden and unexplained death.

After the diagnosis of the secondary EVD case, the fever threshold was decreased to $\geq 37.7^{\circ} \mathrm{C}$ and the criteria for EVD contacts under surveillance were changed to the presence of increased body temperature and/or EVD-compatible symptoms [15].

history of recent travel to an EVD-affected area (33\%; Table 4).

\section{Discussion}

Our study describes 242 EVD-related inquiries received at the Department during the EVD epidemic in 2014. All of these were highly specialised requests, previously triaged by SUMMA 112.

Four distinct phases may be observed in our study. During the first period, from the issue of an international EVD alert on 1 April 2014 to the repatriation of the first healthcare worker on 7 August, only three inquiries were received. The second period between 8 August and the date of diagnosis of the first autochthonous case of EVD in Spain on 6 October was characterised mainly by inquiries related to travellers arriving to Spain from African countries. Noticeably, none of the inquiries during this period were related to contact monitoring of the healthcare workers caring for the repatriates, probably because self-monitoring only was recommended when no breach of the protocol for using the personal protective equipment was reported $[11,12,14]$. The diagnosis of EVD in the healthcare worker on 6 October marked the beginning of the third period of what may be called a public health crisis. In the first hours and days after the information was published, the official communications were limited because the public health authorities were still conducting an investigation into the mode of transmission and tracing contacts [12]. For a few days, the media became the main source of updated information $[16,17]$ and their constant and overwhelming focus on the case contributed to a panic in the population reflected in the peak of inquiries in the second and third week of October. Eventually, the government adopted a set of measures to improve the communication with the public (establishing a national Special Committee on Ebola Management, a webpage and a twitter account), all contacts were traced and controlled, the secondary case recovered. In this fourth period, the focus of the consultations turned back to travellers. However, notwithstanding certain deficiencies in the risk communication on behalf of the authorities, a disease as

contagious and lethal as EVD encountered outside of its natural environment will inevitably cause social alarm and raise a wave of questions, fears and insecurities in the community. Similar evolution of EVD-related inquiries before, during and after a diagnosis of a cluster of three EVD cases in the US $[18,19]$ was reported at the Centers for Disease Control and Prevention (CDC) [20].

Throughout the study period, we experienced various difficulties with the application of the EVD protocol. Before the diagnosis of the autochthonous EVD case, the expected route of introduction of EVD to the country was through travellers arriving to Europe from West Africa [21], and the first Spanish national EVD protocol focused on this scenario [14]. Medical evacuation of EVD cases was treated in a separate protocol [22] and was not a priori considered risky because operations were supposed to happen under the strictest infection control measures. Application of the case criteria in this period was rigorous, but even then, it was not as straightforward as one may expect. Many of the consulted cases in this period, for example, were African migrants returning from summer vacation in their homeland via Lagos international airport. The only affected states in Nigeria were Lagos and Rivers, but most of the consulted cases had stayed in other areas or even in other countries and only spent a few hours in Lagos at the airport on their way back, so the probability of a sustained contact with a symptomatic EVD case was very low. Because of the low specificity of the EVD symptoms, it was often difficult for the public health officers to decide whether to activate the EVD protocol, which would mean an admission to the reference hospital under strict isolation measures for several days, especially when other diagnoses such as malaria were much more likely [23]. This was probably taken into consideration when defining the epidemiological criteria during the outbreak in Mali in November 


\section{TABLE 1}

Topic of inquiries related to the Ebola virus disease and alert notifier, Community of Madrid, Spain, 1 April-2 December $2014(\mathrm{n}=242)$

\begin{tabular}{|c|c|c|c|c|c|c|c|c|c|c|}
\hline \multirow[b]{2}{*}{ Notifier } & \multicolumn{10}{|c|}{$\begin{array}{c}\text { Inquiry topic } \\
n(\%)\end{array}$} \\
\hline & $\begin{array}{c}\text { Clinical } \\
\text { consultation } \\
\text { about a } \\
\text { possible } \\
\text { Ebola virus } \\
\text { disease case }\end{array}$ & $\begin{array}{l}\text { Possible } \\
\text { contact } \\
\text { with the } \\
\text { secondary } \\
\text { case }\end{array}$ & $\begin{array}{l}\text { Possible } \\
\text { contact } \\
\text { with } \\
\text { another } \\
\text { Ebola virus } \\
\text { disease } \\
\text { case }\end{array}$ & $\begin{array}{l}\text { Contact } \\
\text { monitoring }\end{array}$ & $\begin{array}{l}\text { Follow-up of } \\
\text { cases under } \\
\text { investigation }\end{array}$ & $\begin{array}{l}\text { General } \\
\text { questions } \\
\text { about } \\
\text { Ebola virus } \\
\text { disease }\end{array}$ & Complaints & Bioterrorism & Unknown & Total \\
\hline $\begin{array}{l}\text { Emergency } \\
\text { services }\end{array}$ & $24(18)$ & $2(3)$ & 0 & $1(5)$ & 0 & 0 & $1(13)$ & $1(33)$ & 0 & $29(12)$ \\
\hline Primary Care & $42(32)$ & $5(9)$ & 0 & 0 & $1(25)$ & $2(22)$ & $1(13)$ & 0 & $2(67)$ & $53(22)$ \\
\hline Hospital & $43(32)$ & $9(16)$ & 0 & $4(20)$ & $2(50)$ & $1(11)$ & 0 & 0 & o & $59(24)$ \\
\hline $\begin{array}{l}\text { Occupational } \\
\text { Health } \\
\text { Department }\end{array}$ & $2(2)$ & $2(3)$ & 0 & $8(40)$ & 0 & $1(11)$ & 0 & 0 & 0 & $13(5)$ \\
\hline $\begin{array}{l}\text { Border Health } \\
\text { Control }\end{array}$ & $5(4)$ & 0 & 0 & $1(5)$ & 0 & 0 & 0 & 0 & 0 & $6(2)$ \\
\hline Private citizen & $8(6)$ & $33(57)$ & $4(100)$ & $3(15)$ & $1(25)$ & $2(22)$ & $4(50)$ & $1(33)$ & $1(33)$ & $57(24)$ \\
\hline Other/Unknown & $9(7)$ & 7 (12) & 0 & $3(15)$ & 0 & $3(33)$ & $2(25)$ & $1(33)$ & 0 & $25(10)$ \\
\hline Total & $\begin{array}{c}133 \\
(100)\{55\}\end{array}$ & $\begin{array}{c}58 \\
(100)\{24\}\end{array}$ & ${ }^{4}{ }^{4}\{00\}$ & $\begin{array}{c}20 \\
(100)\{8\}\end{array}$ & ${ }^{4}{ }^{4}\{00\}$ & $\stackrel{9}{(100)}\{4\}$ & $\begin{array}{c}8 \\
(100)\{3\}\end{array}$ & $\stackrel{3}{(100)}\{1\}$ & $\stackrel{3}{(100)}\{1\}$ & $\begin{array}{c}242 \\
(100)\{100\}\end{array}$ \\
\hline
\end{tabular}

() Percentage in column. \{\} Percentage in row.

\section{TABLE 2}

Characteristics and management of cases handled via the Ebola virus disease consultation, Community of Madrid, Spain, 1 April-2 December $2014(\mathrm{n}=215)$

\begin{tabular}{|c|c|c|c|c|c|c|}
\hline \multirow[b]{2}{*}{ Topic of the consultation } & \multicolumn{6}{|c|}{$\mathrm{n}$ (\% of the total of clinical consultations) } \\
\hline & Symptoms ${ }^{a}$ & $\begin{array}{l}\text { Clinical } \\
\text { criterion }\end{array}$ & $\begin{array}{l}\text { Epidemiological } \\
\text { criterion }\end{array}$ & $\begin{array}{l}\text { Symptoms } s^{\mathrm{a}} \text { and } \\
\text { epidemiological } \\
\text { criterion }\end{array}$ & $\begin{array}{l}\text { Clinical and } \\
\text { epidemiological } \\
\text { criterion }\end{array}$ & PCR \\
\hline $\begin{array}{l}\text { Clinical consultation about a } \\
\text { possible Ebola virus disease } \\
\text { case }(n=133)\end{array}$ & 114 (53) & $22(10)$ & $33(15)$ & $28(13)$ & $7(3)$ & $7(3)$ \\
\hline $\begin{array}{l}\text { Possible contact with the } \\
\text { secondary case }(n=58)\end{array}$ & 27 (13) & $4(2)$ & $4(2)$ & $3(1)$ & 0 & 0 \\
\hline $\begin{array}{l}\text { Possible contact with another } \\
\text { Ebola virus disease case } \\
(\mathrm{n}=4)\end{array}$ & $3(1)$ & $1(0)$ & 0 & 0 & 0 & 0 \\
\hline Contact monitoring $(n=20)$ & $14(7)$ & $4(2)$ & $31(14)$ & $12(6)$ & $4(2)$ & $8(4)$ \\
\hline Total $(n=215)^{b}$ & $158(73)$ & $31(14)$ & $54(25)$ & $43(20)$ & $11(5)$ & $15(7)$ \\
\hline
\end{tabular}

a Symptoms compatible with Ebola virus disease: fever (or dysthermia), headache, vomiting, diarrhoea, abdominal pain, unexplained haemorrhagic manifestations, multiple organ failure, sudden and unexplained death.

b Some cases may be represented in more than one column.

to December 2014: passing through the Bamako International Airport only was excluded. On the other hand, it was difficult to strictly adhere to the body temperature criterion in persons returning from countries with intense EVD transmission and release cases who had EVD-compatible symptoms and a fever that did not reach the threshold just yet. Indeed, we later witnessed that even the secondary EVD case did not get high-grade fever until several hours after admission to the emergency department [11].

Following the protocol actually delayed the diagnosis of the secondary EVD case from the onset of mild symptoms of malaise and low-grade fever on 30 September until 6 October because there was no reported history of personal protective equipment failure and the presentation of EVD was unusual, i.e. 


\section{TABLE 3}

Presence of Ebola virus disease symptoms in the clinical cases consulted with the Department of Public Health Alerts. Community of Madrid, Spain, 1 April-2 December $2014(\mathrm{n}=215)$

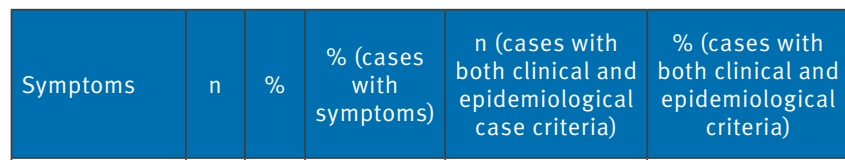

\begin{tabular}{|l|c|c|c|c|c|}
\hline No & 41 & 19 & NA & 0 & 0 \\
\hline Yes $^{\text {a }}$ & 158 & 73 & 100 & 11 & 100 \\
\hline Fever & 124 & 58 & 78 & 11 & 100 \\
\hline Fatigue & 47 & 22 & 30 & 6 & 55 \\
\hline Headache & 45 & 21 & 28 & 6 & 55 \\
\hline Vomiting & 34 & 16 & 22 & 2 & 18 \\
\hline Diarrhoea & 31 & 14 & 20 & 3 & 27 \\
\hline Myalgia & 30 & 14 & 19 & 4 & 36 \\
\hline Sore throat & 27 & 13 & 17 & 2 & 18 \\
\hline Arthralgia & 12 & 6 & 8 & 0 & 0 \\
\hline $\begin{array}{l}\text { Haemorrhagic } \\
\text { symptoms }\end{array}$ & 2 & 1 & 1 & 0 & 0 \\
\hline Unknown & 10 & 5 & NA & 0 & 0 \\
\hline $\begin{array}{l}\text { Not } \\
\text { applicable }\end{array}$ & 6 & 3 & NA & 0 & 100 \\
\hline Total & $\mathbf{2 1 5}$ & $\mathbf{1 0 0}$ & NA & $\mathbf{1 1}$ & \\
\hline
\end{tabular}

NA: not applicable.

a Cases may have presented with more than one symptom.

paucisymptomatic without clinical signs described in the EVD protocols valid at that time and body temperature below the established threshold [14]. The original national and international protocols had been based on data obtained in outbreaks in Africa and were not sensitive enough for monitoring healthcare workers in contact with an EVD patient. Our experience motivated the European Centre for Disease Prevention and Control to reassess the EVD risk for Europe [24] and led to the adaptation of the EVD protocols to include recommendations for healthcare worker contact monitoring $[15,25,26]$. After the diagnosis of the secondary case, the criteria for testing an individual for the presence of Ebola virus were applied more loosely and several healthcare workers were isolated and tested even if they did not fulfil the clinical criteria or if there were doubts about direct contact with any of the EVD cases, just to prevent possible further transmission.

An important part of the workload at the Department during the first days of the outbreak was, besides carrying out the epidemiological investigation and tracing the contacts, dealing with inquiries from private citizens who mostly did not fulfil either the clinical or the epidemiological criteria. Speculations about possible routes of EVD transmission in the media (mainly transmission by air and through fomites) caused a lot of anxiety in the neighbourhood of the secondary EVD case: more than two thirds of the inquiries (40/57) from private citizens were related to the secondary EVD case.
TABLE 4

Recent travel history in relation with consultations on possible Ebola virus disease, Department of Public Health Alerts, Community of Madrid, Spain, 1 April-2 December $2014(\mathrm{n}=96)$

\section{Country} n (\%)

Ebola-virus affected countries

\begin{tabular}{|l|c|}
\hline Nigeria (Lagos) ${ }^{\mathrm{a}}$ & $19(20)$ \\
\hline Guinea & $6(6)$ \\
\hline Liberia & $1(1)$ \\
\hline Malia $^{\mathrm{a}}$ & $2(2)$ \\
\hline Sierra Leone & $4(4)$ \\
\hline
\end{tabular}

Ebola-virus affected country but not in the affected provinces

\begin{tabular}{|l|l}
\hline Democratic Republic of Congo $^{\mathrm{a}}$ & 5 (5) \\
\hline
\end{tabular}

\begin{tabular}{|l|l}
\hline Nigeria $^{a}$ & $4(4)$
\end{tabular}

Countries not affected by the Ebola virus outbreak

\begin{tabular}{|c|c|}
\hline Equatorial Guinea & $16(17)$ \\
\hline Malib $^{\mathrm{b}}$ & $6(6)$ \\
\hline Senegal $^{c}$ & $6(6)$ \\
\hline Morrocco & $4(4)$ \\
\hline Tanzania & 3(3) \\
\hline Côte d'Ivoire & $2(2)$ \\
\hline Gambia & $2(2)$ \\
\hline Ghana & $2(2)$ \\
\hline Other African countries ${ }^{d}$ & $6(6)$ \\
\hline Europe $^{\mathrm{e}}$ & $3(3)$ \\
\hline The Americas ${ }^{f}$ & $2(2)$ \\
\hline East Mediterranean ${ }^{g}$ & $1(1)$ \\
\hline Asiah $^{h}$ & $1(1)$ \\
\hline Unknown & $1(1)$ \\
\hline Total & $96(100)$ \\
\hline
\end{tabular}

a Visited during the period of the outbreak (Nigeria: 23 July-20 October 2014, Democratic Republic of Congo: 11 August-20 November 2014, Mali: 23 October 2014-18 January 2015).

${ }^{b}$ Visited when not affected by Ebola virus transmission.

' Senegal was never included in the list of affected countries in the Spanish Ebola virus disease protocol.

${ }^{d}$ Angola, Cameroon, Ethiopia, Somalia, Togo and Zambia: 1 inquiry each.

e Turkey $(n=2)$, the Netherlands $(n=1)$.

${ }^{f}$ Cuba $(n=1)$, Peru $(n=1)$.

g Saudi Arabia.

h China.

Two high-risk and one low-risk contact were identified through these inquiries; the remaining 84 contacts were traced through standard outbreak investigation procedures [12]. Many callers experienced at least one EVD-compatible symptom, most commonly fever, headache and gastrointestinal symptoms. But these symptoms have low specificity and may be stress-induced, and many people who thought they had come into contact with the secondary case suffered these symptoms almost immediately after the news were released 
[27], even before the incubation period would have been over. The rest of the inquiries were related mainly to recent travel abroad or contact with foreigners or migrants of African origin.

Our data allowed us to evaluate the communication problems that occurred in an emergency situation. Considerable effort was made to raise the awareness about EVD among clinicians and nurses following the arrival of the first repatriated case, but many did not read the EVD protocol, although it was easily accessible online, had been sent out by email and there was a large banner on the homepage of the public healthcare service intranet. The facts that not even $5 \%$ of the persons whose cases were consulted fulfilled strictly both the clinical and the epidemiological criteria and that two thirds of the traveller inquiries were not related to areas affected by EVD indicate that one of the fundamental aspects of crisis management in the future has to be active communication with the healthcare workers to avoid unnecessary case classification errors. On the other hand, we have to keep in mind that physicians are not immune to experiencing fear in the face of EVD, that they may worry about the legal consequences of not detecting EVD in a patient or feel responsible for possibly exposing the rest of the healthcare team, other patients and ultimately even their own family to a severe disease. Therefore, it is natural that they choose to contact an epidemiologist in case of doubt. In addition, we must not forget that many medical consultations in primary care and hospitals were resolved correctly without help from the Department. Our results are very similar to those reported by Karwowski et al. who analysed the inquiries received by the $\mathrm{CDC}$ from clinicians and local health departments in the US [20]. In their study, $75 \%$ of the concerned cases did not have any history of contact with EVD (vs $75 \%$ in our study), $21 \%$ had travelled to an Ebola-affected country (vs $19 \%$ of the clinical inquiries related to travel to an Ebola-virus affected country in our study), $18 \%$ had symptoms consistent with EVD and epidemiological risk factors (vs $20 \%$ in our study), and $9 \%$ were tested for Ebola virus (vs $7 \%$ in our study). It is clear that public health authorities need to reassess their communication strategy, making sure their message is heard where it is needed the most, i.e. in the patient examination rooms.

Our experience illustrates the importance of establishing a rapid response consultation service by telephone that offers fast and qualified answers to any questions that may arise during public health emergencies. Such systems may also help find contacts not detected through the epidemiological investigation, as happened in our case. We hope that sharing our experience may help public health professionals in other countries dimension their activities and resources for managing similar exceptional outbreaks in the future.
The Working group of the Madrid Ebola outbreak investigation team

María Carmen Álvarez-Castillo, Andrés Aragón-Peña, Carlos Cevallos-García, María Jesús Gascón-Sancho, Margarita Hernando-García, Consuelo Ibáñez-Martí, Susana JiménezBueno, María Dolores Lasheras-Carbajo, Fernando MartínMartínez, Honorato Ortiz-Marrón, Elena Rodríguez-Baena, José Antonio Taveira-Jiménez.

\section{Conflict of interest}

None declared.

\section{Authors' contributions}

M.A. Lópaz-Pérez and J. Astray-Mochales designed the study. V. Blaya-Nováková performed a literature search, collected the data, analysed the data, and wrote the first draft of the manuscript. All authors interpreted and discussed the results, edited, and commented on the manuscript draft.

\section{References}

1. World Health Organization (WHO). Ebola response roadmap - Situation report. Geneva: WHO. [Accessed 8 Jun 2015]. Available from: http://www.who.int/csr/disease/ebola/ situation-reports/en/

2. World Health Organization (WHO). Ebola virus disease, West Africa - update. Geneva: WHO. [Accessed 8 Jun 2015]. Available from: http://www.who.int/csr/don/2014_07_27_ebola/en/

3. World Health Organization (WHO). Ebola virus disease update Senegal. Geneva: WHO. [Accessed 8 Jun 2015]. Available from: http://www.who.int/csr/don/2014_08_30_ebola/en/

4. World Health Organization (WHO). Ebola virus disease Spain. Geneva: WHO. [Accessed 8 Jun 2015]. Available from: http://www.who.int/csr/don/og-october-2014-ebola/en/

5. World Health Organization (WHO). Ebola virus disease - United States of America. Geneva: WHO. [Accessed 8 Jun 2015]. Available from: http://www.who.int/csr/ don/o1-october-2014-ebola/en/

6. World Health Organization (WHO). Ebola virus disease - Mali. Geneva: WHO. [Accessed 8 Jun 2015]. Available from: http:// www.who.int/csr/don/31-october-2014-ebola/en/

7. World Health Organization (WHO). Ebola virus disease - United Kingdom. Geneva: WHO. [Accessed 8 Jun 2015]. Available from: http://www.who.int/csr/don/30-december-2014-ebola/en/

8. World Health Organization (WHO). Ebola virus disease - Italy. Geneva: WHO. [Accessed 8 Jun 2015]. Available from: http:// www.who.int/csr/don/13-may-2015-ebola/en/

9. World Health Organization (WHO). Ebola virus disease in Guinea. Geneva: WHO. [Accessed 8 Jun 2015]. Available from: http://www.afro.who.int/en/clusters-a-programmes/ $\mathrm{dpc} /$ epidemic-a-pandemic-alert-and-response/outbreaknews/4063-ebola-hemorrhagic-fever-in-guinea.html

10. Información sobre el brote de enfermedad por virus Ébola (EVE). Fecha de información inicial alerta 01.04.2014. [Information about the outbreak of Ebola virus disease. Date of initial alert 1 April 2014]. Madrid: Ministerio de Sanidad, Servicios Sociales e Igualdad; 2014. [Accessed: 13 Dec 2014]. Spanish. Available from: https://www.msssi.gob.es/ profesionales/saludPublica/ccayes/alertasActual/ebola/home. $\mathrm{htm}$

11. ParrajM, SalmerónOJ, VelascoM. The first case of Ebola virus disease acquired outside Africa.N Engl J Med. 2014;371(25):2439-40. DOI: 10.1056/NEJMC1412662 PMID: 25409262

12. LópazMA, AmelaC, OrdobasM, Domínguez-BerjonMF, ÁlvarezC, MartínezM, et al. First secondary case of Ebola outside Africa: epidemiological characteristics and contact monitoring, Spain, September to November 2014. Euro Surveill. 2015;20(1):21003. DOI: 10.2807/1560-7917.ES2015.20.1.21003 PMID: 25613651

13. World Health Organization (WHO). WHO congratulates Spain on ending Ebola transmission. Geneva: WHO. [Accessed 8 Jun 2015]. Available from: http://www.who.int/mediacentre/news/ statements/2014/spain-ends-ebola/en/

14. Protocolo de actuación frente a casos sospechosos de enfermedad por virus Ébola (EVE). [Protocol for management of 
suspected cases of Ebola virus disease]. Madrid: Ministerio de Sanidad, Servicios Sociales e lgualdad; 15 Sep 2014. Spanish. Available from: http://www.madrid.org/cs/Satellite?blobcol =urldata\&blobheader=application $\% 2 \mathrm{Fpdf} \&$ blobheadernam e1=Content-disposition\&blobheadername $2=$ cadena\&blobhe adervalue $1=$ filename $\% 3$ DProtocolo + de + actuaci $\% C_{3} \% B_{3} n+E$ VE $15+09+2014+$ CM.pdf\&blobheadervalue $2=$ language $\% 3$ Des $\% 26$ site $\% 3$ DPortal Salud\&blobkey=id\&blobtable=MungoBlobs \&blobwhere $=1352862624042 \&$ ssbinary $=$ true

15. Protocolo de actuación frente a casos sospechosos de enfermedad por virus Ébola (EVE). [Protocol for management of suspected cases of Ebola virus disease]. Madrid: Ministerio de Sanidad, Servicios Sociales e Igualdad; 26 Nov 2014. Spanish. Available from: https://www.msssi.gob.es/profesionales/ saludPublica/ccayes/alertasActual/ebola/docs/5.12.2014_ Protocolo-Ebola.pdf

16. RobinsonSJ, NewstetterWC. Uncertain science and certain deadlines: CDC responses to the media during the anthrax attacks of 2001.J Health Commun. 2003;8(Suppl 1);17-34, discussion 148-51. DOI: 10.1080/713851980 PMID: 14692570

17. GarrettL. Understanding media's response to epidemics.Public Health Rep. 2001;116(Suppl 2):87-91. DOI: 10.1016/So0333549(04)50149-8 PMID: 11880679

18. McCartyCL, BaslerC, KarwowskiM, ErmeM, NixonG, KippesC, et al. Response to importation of a case of Ebola virus disease--Ohio, October 2014. MMWR Morb Mortal Wkly Rep. 2014;63(46):1089-91.PMID: 25412070

19. ChevalierMS, ChungW, Smith), WeilLM, HughesSM, JoynerSN, et al. Ebola virus disease cluster in the United States-Dallas County, Texas, 2014. MMWR Morb Mortal Wkly Rep. 2014;63(46):1087-8.PMID: 25412069

20. KarwowskiMP, MeitesE, FullertonKE, StröherU, LoweL, RayfieldM, et al. Clinical inquiries regarding Ebola virus disease received by CDC--United States, July 9-November 15 , 2014. MMWR Morb Mortal Wkly Rep. 2014;63(49):1175-9.PMID: 25503923

21. SprengerM, CoulombierD. Preparedness is crucial for safe care of Ebola patients and to prevent onward transmission in Europe - outbreak control measures are needed at its roots in West Africa.Euro Surveill. 2014;19(40):20925. DOI: 10.2807/1560-7917.ES2014.19.40.20925 PMID: 25323074

22. Protocol to be followed in medical air evacuation of patients suffering from the Ebola virus. Madrid: Ministerio de Sanidad, Servicios Sociales e Igualdad; 5 Sep 2014. Available from: https://www.msssi.gob.es/profesionales/ saludPublica/ccayes/alertasActual/ebola/docs/ Protocolo_aeroevacuacion_05092014_EN.pdf

23. BoggildAK, EspositoDH, KozarskyPE, AnsdellV, BeechingNJ, CampionD, et al. Differential diagnosis of illness in travelers arriving from Sierra Leone, Liberia, or Guinea: a crosssectional study from the GeoSentinel Surveillance Network. Ann Intern Med. 2015;162(11):757-64. DOI: 10.7326/M15-0074 PMID: 25961811

24. European Centre for Disease Prevention and Control (ECDC). Ebola case in Spain: ECDC to re-assess transmission risk for Europe. Stockholm: ECDC; 2014. [Accessed 8 Jun 2015]. Available from: http://ecdc.europa. eu/en/press/news/_layouts/forms/News_DispForm. aspx? List $=8 \mathrm{db} 7286 \mathrm{c}-\mathrm{fe} 2 \mathrm{~d}-476 \mathrm{c}-9133-18 \mathrm{ff}_{4} \mathrm{cb} 1 \mathrm{~b} 568 \& \mathrm{ID}=1080$

25. European Centre for Disease Prevention and Control (ECDC). Public health management of persons having had contact with Ebola virus disease cases in the EU. Stockholm: ECDC; 9 Oct 2014. Available from: http://www.ecdc.europa.eu/ en/publications/Publications/ebola-public-health-contactmanagement-update-10-November.pdf

26. Centers for Disease Control and Prevention (CDC). Infection prevention and control recommendations for hospitalized patients with known or suspected Ebola virus disease in U.S. hospitals. Atlanta: CDC. [Accessed 2014 Dec 14]. Available from: http://www.cdc.gov/vhf/ebola/hcp/infection-preventionand-control-recommendations.html

27. RubinGJ, AmlôtR, CarterH, LargeS, WesselyS, PageL. Reassuring and managing patients with concerns about swine flu: qualitative interviews with callers to NHS Direct.BMC Public Health. 2010;10(1):451. DOI: 10.1186/1471-2458-10-451 PMID: 20678192 